\title{
The Research on Management of Private Enterprise in Diversification Strategy Environment
}

\author{
Lequn LI \\ Hunan Mass Media Vocational Technical College \\ Changsha,Hunan, 410100 China
}

\begin{abstract}
Diversification strategy takes a more important part in business management, with the deepening development of the market economy, most international companies began to use the diversified strategy. According to relevant statistics, more than $94 \%$ of the world 500 enterprises implemented diversified business strategy. China's most enterprises from the late 1980s began diversification strategy. But for the private enterprises, the application of diversification strategy to private enterprises can not only promote the rational use of corporate capital flows and thus improve the economic efficiency of private enterprise, but also take advantage of private enterprises to improve the core competitiveness of private enterprises. However, private enterprise diversification strategy has successful stories with also some cases of failure, and not all private enterprises are suitable for the implementation of private enterprise diversification strategy.
\end{abstract}

Keywords- Diversification strategy, private enterprises, management

\section{INTRODUCTION}

Diversification strategy is a double-edged sword, which shows that not all businesses are suitable for diversification strategy. If private enterprises adopt diversification strategy timing was not right, conditions are not ripe, private enterprises' resources will inevitably be dispersed, the cost of private enterprises will be increased, private enterprises management efficiency will be reduced, and the difficulty of the management of private enterprises will be increased. The result can not only fail to get the original positive results of diversification, but will make private enterprise lost its main business competitive advantage, and even lead to the failure of private enterprise management. Therefore, private enterprises must own some conditions in the implementation of the diversification strategy to.

\section{THE BASIC MEANING OF DIVERSIFIED STRATEGY}

Diversified strategy, also known as diversification or diversification, refers to different strategies that enterprises use while operating in a number of different business-related or not related to the industries. Diversification strategy originated in the Western portfolio investment business, and then a business development strategy is proposed based on large enterprise scale, financial strength, strong risk diversification ability, strong marketing capability and the ability to adapt to the characteristics of the poor to come. From the point of view that a variety of domestic and foreign enterprises' implemented diversified business strategies, it is mainly to solve two problems: First, disperse enterprise risk. Large enterprises tend to be the center of the industry, expand to other areas in the form of a sideline to disperse operating risks; second, to effectively use business resources, it develops towards the related areas of technology and markets.

Diversification strategies in the business strategy belong to product, market strategy. It is produced with the cooperation of new product areas and new markets, namely the strategy happening in addition of new product categories and new markets. Diversified business enterprises to provide products and services for a particular enterprise market, and also enters other markets. In other word, businesses to maximize economic efficiency and long-term stability operations, develop potential products, or through absorption, emergence with other industry enterprises, enrich the family structure or rich product mixture structure.

\section{DIVERSIFIED BUSINESS MODEL DIVERSIFIED BUSINESS MODEL REQUIREMENTS OF PRIVATE BUSINESS}

In the diversified business model, private companies recognize the importance of the technology, product and the market, but lack understanding of the importance of diversification and the requirements mode of operation. Therefore, most private enterprise management is basically still in the stage of one dimensional management. A dimensional management put too much emphasis on the organization and management of the program management system. With the continuous development and growth of private enterprises, diversified business model requirements of private enterprises will be higher. Private enterprises are faced with the following problems:

\section{A. Consummate corporate regulations}

On private enterprise management, consummate enterprise organization and management system, personnel management, production management, financial management, marketing management system, and perfect worker health insurance, social insurance management system. Organizational system management will establish organizations suited to the organization's overall operations of private enterprise. Business organization and management 
systems enable organizations to achieve enough clear division of labor, clear responsibilities in the management. Formulate and implement private enterprises in various positions of responsibility. Mainly targets the actual work in various positions and responsibilities, and establish the first responsibility to develop and implement job functions of various departments. Department is mainly responsible for the scope of work and responsibilities.

Private companies will be given the superior benefits to workers. From the point of view of enterprise management level expand the scope of the concept of a diversified business model and diversified business model at different levels of private enterprises in the role and performance of the way. Different management levels need to work together to support the overall business activities so that diversified business model operate smoothly.

\section{B. Requirements of compound management personnels}

In the modern market economy, private enterprises recognize the talents flow faster and faster, which requires more flexible management mechanism. The rapid development of private enterprises, compound management talents show outstrip supply, especially the lack of senior management and technical personnels.

Private enterprise should develop the personnel management system suitable for business, and mainly establish corporate rules and regulations, including staff recruitment, staff training, management of personnel changes, personnel appraisal appraisal, employee motivation, employee attendance management and personnel records management, and many other aspects. Enterprise management process should be rule-based according to the law. Many private companies recognize the importance of talents, and the higher wage income or other substances incentives to attract talent, but in the process of human resources management, simply rewarding to motivate employees to increase passion, ignoring good nurturing environment of the organization, makes enterprises lack cohesion and a sense of belonging for workers.

\section{Capital accumulation and flowing}

In private enterprise management process, the accumulation of capital and liquidity is a very critical aspect. This case often occurs in private enterprises when they realize that it is already too late when corporate capital arises, there is no remedy. To prevent this from happening, many private companies will develop specific regulations, and hire dedicated staff to manage its capital. An effective way to prevent this from happening is to regularly inspect corporate capital case, if we find risk factors, they should immediately be stopped.

\section{Focus on the content and quality of staff training}

Recognizing the role of human resources is very important for companies; so many private enterprises attach great importance to the training of employees, and will invest the amount of time and effort for staff training professional system. Of course, the content of the training should be jobrelated and ensure that employees receive training to betterly complete the work. In other word, training is related to the employee's work, and training should also be able to help employees' personal development. In addition, the development, setting training, implementation and training of the training program, as well as various aspects of convergence between work and so are the challenges faced in training. Overall, China's private enterprises management, most people still take a unified management model, or family management or experience in management and so on. In particular, family private enterprise, and many management systems are "cronyism" and lack specialized management personnel and a single management system. How to attract talent management system specification is now the key to the institutionalization of private enterprises diversified management mode. How rational allocation of human resources, give full play to the role of human resources in the enterprise, and ultimately achieve the harmonious development of enterprises, it is very important.

\section{PROBLEMS OF PRIVATE ENTERPRISE DIVERSITY}

In the process of private enterprises diversification, diversification war generally slightly lacked scientific understanding. They see more advantage of diversification, but not aware of the problems and the risk of diversification. A considerable number of private enterprises get into a wide range of difficulties.

Learning lessons through diversified private enterprises, it can be summarized that private enterprises in China exist the following problems of diversification:

\section{A. Operators "speculation"}

At the beginning of the reform, the Chinese market is a huge potential emerging market which there is many areas of excessive profits, but unstable market environment must be accompanied by a huge potential risk. As the pursuit of high profits mentality, so many Chinese private enterprises are jumping around in different industries, rather than directly facing the competition to improve their competitiveness. The results of this blind diversification often go contrary to the wishes.

\section{B. Expand too fast}

Diversification has inherent risks, that is, when companies just enter a field, and take not an absolute advantage or even no advantage at all. So in the early period of diversification, grasp the rate of expansion, pay attention to rhythm. But the Chinese enterprises are not many private in-depth investigation and feasibility study which areas the heat, which will invest resources in the field, the result is that enterprises in cross-sectoral, cross-sectoral, inter-regional, while the loss of their products, market advantage and regional advantages, to bring a great deal of risk.

\section{Blindly expand unrelatedly}

Diversification of enterprises may play effects to cost reduction a risk diversification and so on , but excessively pursuit of diversification leads to coordinate activities more difficult, will inevitably increase the operational risks. Chinese private enterprises are carried unrelated 
diversification, so that enterprises can not obtain economies of scale and scope economies, the opposite would divert limited resources of enterprises, increasing operational risks.

\section{RECOMMENDATION OF BUSINESS DIVERSIFICATION STRATEGY}

\section{A. Perfect internal mechanisms}

Internal mechanism is an important part of enterprise's development, and enterprise's management center. An enterprise chooses diversification, such as the original internal mechanisms, namely the division of labor, collaboration, distribution of responsibilities and interests of damage, and there must be a new mechanism to compensate for all this, or it is likely to cause confusion in management. Enterprise diversification in time, we must consider this a problem, and by adjusting the relevant system or mechanism to allow companies to adapt slowly diversified business strategy. All this should properly handle the division of labor, balance coordination, responsibilities and benefits of the relationship, especially in the distribution of benefits. This all done so that companies can wholeheartedly on diversification force, to get rid of the internal management of possible confusion caused by increased business costs.

\section{B. Consummate business resource management}

Enterprise resource management is a business challenge; it decides whether the business can be a good use of their resources. Every enterprise's resources are limited. However, how limited resources are able to play unlimited energy lies in how to use these resources in the enterprise, whether on the right are use. Corporate earnings and the company's assets have a direct relationship, preferably with their own independent enterprise asset management team, detailed asset management and real-time quantization control. Through the establishment of an effective internal market and external markets, to complete the effective management of assets, Internal market management product development, production, and service, the external market is mainly the product to market. Improve the management of assets; management and corporate management to quantify return on assets most effectively optimize the utilization efficiency of assets.

\section{Private enterprises should adhere to the exploration of diversification}

Diversification strategy as a business management major academic business strategy, is neither a panacea to save the business to avoid bankruptcy, nor directly lead to the demise of private enterprises to embark on the culprit. Relevant statistics show that in all private listed companies, nearly three-quarters of a listed company involuntary gone the way of diversification can be seen between diversification and business performance. There is no significant correlation between diversities. Although there is no operation bringing higher operating profit, but to a certain extent, decentralized operating risks explore new profit growth point of the enterprise. Successful implementation of the diversification strategy must have a sound strategic analysis. First of all, from the point of view of the political, economic, cultural and technical external macro environment, analysis to determine whether they have diversified to explore the current macroeconomic conditions; second, take advantage of SOWT analysis tool, and identify strengths and weaknesses in corporate diversification strategy implementation process. Professional business enterprise implementing diversification is a gradual process, it is impossible to jump in. Therefore, the road of private enterprise diversification to explore should be detailed and objective analysis of the company will enter the industry to explore the characteristics and their available resources, the use of internal capital markets, improve the efficiency of resource use in general, so you can take advantage of the synergies between the resources to improve their economic performance.

\section{Excellent team of professional managers}

Through empirical research, it shows that the same diversification strategy, some companies after the demise of the glory to the application, and the application of some companies are entering the business of second life cycle. Thus, the importance of the management team, business entering the diversification and professional management, the existing management and organizational structures will be significant changes in the strategic application process. Improving the management skills of the management team are two main ways: on one hand, enterprises should strengthen the management of the senior managers, especially the vocational training; on the other hand, companies can employ both ability and integrity in the labor market in the form of external professional managers. Competitive level, the more important the role of human resources in the critical period of strategic transformation, if corporate executives do not have the appropriate management of the arts, the implementation of the diversification strategy will enable enterprises to chaos in the capital, manpower allocation, a key part of any mistake may have resulted in the failure of diversification strategy.

\section{REFERENCES}

[1] Peng Shulan. Private enterprise diversification strategy under management [J]. Modern Economic Information, 2011.

[2] Song Liqiu, Wang Jinghua. Private enterprises Management of diversification strategy under [J]. Chinese commerce,2011,30:95-96.

[3] Zhang Nan, Ling Yan. Diversification of Private Enterprise Management Strategy of [J]. Chinese commerce,2012,12:63-64.

[4] Yang Jingjing. political association of private enterprises, research [D]. Relationship between diversification strategy and performance., South China University of Technology, 2013.

[5] Liu Peng. Empirical Study of Private Enterprise diversification strategy and business performance relationship [D]. Mongolia University of Finance and Economics, 2012. 